\title{
Development and industrialisation of enzymatic shrink-resist process based on modified proteases for wool machine washability
}

\author{
Jinsong Shen ${ }^{\mathrm{a}, *}$, Mike Rushforth ${ }^{\mathrm{b}}$, Artur Cavaco-Paulo ${ }^{\mathrm{c}}$, \\ Georg Guebitz ${ }^{\mathrm{d}}$, Herman Lenting ${ }^{\mathrm{e}}$ \\ a Textile Engineering and Materials (TEAM) Research Group, De Montfort University, The Gateway, Leicester LE1 9BH, UK \\ ${ }^{\mathrm{b}}$ Global Textile Associates Ltd., Skipton, UK \\ ${ }^{c}$ Department of Textile Engineering, Minho University, Guimarães, Portugal \\ ${ }^{\mathrm{d}}$ Department of Environmental Biotechnology, Graz University of Technology, Graz, Austria \\ ${ }^{\mathrm{e}}$ Department of Innovative Materials, TNO Industry and Technology, Enschede, The Netherlands \\ Received 15 June 2006; received in revised form 6 July 2006; accepted 22 July 2006
}

\begin{abstract}
There is currently considerable interest in the use of enzymes to achieve a variety of finishing effects on wool, but it is apparent that the extent of fibre degradation by enzymes is of major concern during their commercial application. Proteolytic enzymes are known to penetrate and degrade the internal wool structure during processing, causing fibre damage, rather than limiting the degradation to the cuticle cells. The ability to be able to control the exact location of proteolytic attack on wool protein structures will lead to the successful development of enzymatic treatments for achieving a variety of finishing effects for wool-containing products. This present work describes the modification of proteases so that enzymatic modification of wool fibres is restricted to the cuticle scales of the fibres.

Bulk trials have demonstrated that novel modifications of the enzyme enable the reaction of the enzyme with wool to be controlled, so that less degradation of the wool occurs than in similar treatments with the native protease. An anti-felting effect has been achieved without any significant weight loss being caused by the modified protease during the treatment. This novel enzymatic process leads to environmentally friendly production of machine washable wool.
\end{abstract}

(c) 2006 Elsevier Inc. All rights reserved.

Keywords: Chemical modification; Protease; Wool; Shrink-resistance

\section{Introduction}

There is currently considerable interest in the use of enzymes to achieve a variety of finishing effects on wool [1-5], but it is apparent that the extent of fibre degradation by enzymes is of major concern during their commercial application.

Recent work $[5,6]$ has shown that the activity of proteases towards undamaged wool is slow due to the protection of cuticle cells but once some of the cystine disulphide cross-links in cuticle cells are broken, the rate of enzyme reaction is greatly increased. During the enzymatic treatment with conventional proteases, damage of wool fibres was caused by enzyme penetration into the interior of fibres and breaking down the cell membrane complex. It is difficult to limit enzymatic degrada-

\footnotetext{
* Corresponding author. Tel.: +44 116 2577550; fax: +44 1162577582.

E-mail address: jshen@dmu.ac.uk (J. Shen).
}

tion to the cuticle scales and to achieve machine washable wool without significant fibre damage [7].

A new approach [8-12] has attempted the modification of proteases to increase their molecular sizes in order to limit the enzymatic degradation of wool fibre to their cuticle scales. The increase in molecular size of proteases can be achieved by covalently attaching proteases onto soluble polymer. Preliminary laboratory results have shown that fibre degradation is reduced by modified proteases. It made possible to achieve machine washable wool by enzymatic treatment with modified proteases.

This present work investigated enzymatic processes based on the chemically modified proteases and their effects on wool fabric properties including shrink-resistance and dyeing characteristics. This novel technology has been developed into the stages of the industrialisation process. Industrial levels of trials for application of modified proteases on the wool wet process were undertaken to assess the modification of wool 
fibres and improved shrink-resist properties for wool machine washability.

\section{Materials and methods}

\subsection{Enzyme, chemicals and wool materials}

Esperase $8.0 \mathrm{~L}$ was supplied by Novozymes and stored in a refrigerator at $5{ }^{\circ} \mathrm{C}$. The non-ionic surfactant used in this work is FABRIWET NW supplied by Alphachem Specialities Ltd., UK. All chemicals used were "Technical Grade", as normally used in bulk processing.

The wool fabrics used in all the trials were the plain weave fabrics produced from yarns spun from $19 \mu \mathrm{m}$ and $21 \mu \mathrm{m}$ wools. The fabrics had been commercially scoured and dried before treatment.

\subsection{Modification of Esperase}

Esperase was covalently linked onto Eudragit S100 (a reversible solubleinsoluble polymer) by carbodiimide coupling. The modified Esperase was purified by precipitation of Eudragit-enzyme conjugate, centrifugation separation and re-suspension with buffer. Repeated purification of modified Esperase was carried out by four wash cycles. The modified Esperase was produced by Alphachem Specialities Ltd., UK at $5 \mathrm{~L}$ and $50 \mathrm{~L}$ bulk production scale followed a protocol procedure developed by Silva et al. [12].

The activity of native and modified Esperase towards soluble casein was determined based on the Sigma Quality Procedure for the enzymatic assay of protease. The enzyme is measured by following the increase in absorbance at $660 \mathrm{~nm}$ with a $0.65 \%$ casein solution in $50 \mathrm{mM}$ of a pH 7.5 phosphate buffer as substrate when incubated at $37^{\circ} \mathrm{C}$ [12]. The total protein concentration was determined by the modified micro Lowry method [13], using bovine serum albumin as standard and Sigma test kit no. P5656.

\subsection{Pilot trials for enzymatic shrink-resist process}

\subsubsection{Assembly of wool fabric with polyester lead sheet used in} pilot-scale trials

The pilot trials of enzymatic wool shrink-resist process were carried out in a $50 \mathrm{~L}$, then jet dyeing machine with approximately $10 \mathrm{~m}$ lengths of the fabric made-up from approximately $9 \mathrm{~m}$ of polyester fabric sewn to approximately $2 \mathrm{~m}$ of the full width wool sample fabric in order to use only small quantities of enzymes in each treatment. The protease enzymes are assumed to have no affinity for the polyester lead sheet, so the only fabric protease will be active on is the wool sample fabric. Using this technique, the full width samples of the wool fabric weighs approximately $560 \mathrm{~g}$ in total in the production machine.

The rate of circulation of the fabric is controlled to be at a rate of approximately $5 \mathrm{rpm}$ by a winch reel above the jet. The total volume of liquor in the machine during the enzyme treatment was $35 \mathrm{~L}$ so that the liquor ratio for wool was approximately $62.5: 1$

\subsubsection{Pre-treatment}

Two different pre-treatment methods (A and B) were applied prior to the enzyme application in order to achieve more favourable modification of the wool by the proteases in a jet dyeing machine.

2.3.2.1. Method A. The assembled fabrics were pre-treated at $60^{\circ} \mathrm{C}$ for $15 \mathrm{~min}$ with treatment solution containing $4 \% \mathrm{Na}_{2} \mathrm{CO}_{3}$ on mass of wool fabric and $1.2 \mathrm{~g} / \mathrm{L}$ non-ionic surfactant FABRIWET NW, then this pre-treatment was repeated once in the presence of $1.0 \mathrm{~g} / \mathrm{L}$ non-ionic surfactant.

2.3.2.2. Method B. The assembled fabrics were pre-treated with treatment solution containing $1.2 \mathrm{~g} / \mathrm{L}$ non-ionic surfactant at $\mathrm{pH} 9$ adjusted by $\mathrm{Na}_{2} \mathrm{CO}_{3}$ at $40^{\circ} \mathrm{C}$ for $30 \mathrm{~min}$. After being scoured, fabrics were rinsed twice. The subsequent bleaching process was carried out in the solution containing $1 \% \mathrm{H}_{2} \mathrm{O}_{2}$ (30\%) on mass of wool fabric at $\mathrm{pH} 9$ and $55^{\circ} \mathrm{C}$ for $60 \mathrm{~min}$.

\subsubsection{Enzyme application}

After the pre-treatment, two 1-m samples of wool fabrics from pre-treatment methods A and B were cut and sewn together and then treated with either the native or modified Esperase, using the polyester lead sheet as described in Section 2.3.1.

All treatments were applied with 5 activity unit of native or modified Esperase per gram of wool fabric at $50^{\circ} \mathrm{C}$ for $60 \mathrm{~min}$ and $120 \mathrm{~min}$, one of the $1 \mathrm{~m}$ wool sample pieces being removed from the assembly after $60 \mathrm{~min}$. The concentration of enzyme calculated on the weight of the remaining wool sample would be increased by a factor of two for the second $60 \mathrm{~min}$ period but it was considered that this inconsistency was acceptable if further information about extended or more severe treatments with the enzymes could be gained.

\subsubsection{Dyeing}

The treated wool samples were dyed in the laboratory using a Roaches Pyrotec S laboratory dyeing machine. The fabrics were dyed in a navy shade with acid dyes by following standard dying procedures.

\subsection{Bulk trials of enzymatic shrink-resist process}

All fabric treatments were carried out in the jet dyeing machine, using a $10 \mathrm{~m}$ length of fabric made-up from $5 \mathrm{~m}$ of the $19 \mu \mathrm{m}$ wool fabric and $5 \mathrm{~m}$ of the $21 \mu \mathrm{m}$ wool fabric.

The general treatment procedure used was:

1. Pre-treat with $4 \%$ (omf) sodium carbonate for $30 \mathrm{~min}$ at $50^{\circ} \mathrm{C}$.

2. Drain, warm rinse and then cold rinse.

3. Treat with 5 activity units of native or modified Esperase per grams fabric for $120 \mathrm{~min}$ at $50^{\circ} \mathrm{C}$.

4. Drain, warm rinse and cold rinse.

Dyeing the enzyme treated fabrics is carried out in the separate bath using the same recipe of dyeing process as described in Section 2.3.4 at this bulk process.

The untreated samples had been decatised only.

\subsection{Evaluation}

Following enzyme treatment and dyeing, the fabric was dried and finished using standard commercial processing machinery including fabric drying at a width of $156 \mathrm{~cm}$ using $7 \%$ overfeed on the stenter at $170^{\circ} \mathrm{C}$ and a speed of $7 \mathrm{~m} / \mathrm{min}$, cropping on a piano-bed cropping machine to remove fibres projecting from the surface of the fabric, decatising using a Sellers pressure decatising machine with a high wrapper tension. Then the fabric properties were evaluated.

\subsubsection{Felting shrinkage}

The shrinkage of fabrics was measured according to Woolmark Test Method No. 31. The samples were subjected to a 7A programme for relaxation shrinkage and $5 \mathrm{~A}$ was cycles up to three times for felting shrinkage. The shrinkage was expressed as a percentage of the dimensions of the fabric. The area felting shrinkage is calculated as the sum of the warp and weft shrinkages.

\subsubsection{Tensile properties}

The tensile strength and elongation of fabrics was measured using a Testometric Extensometer. The procedure used was as described in BS EN ISO 13934-1:1999.

\subsubsection{Colour measurements}

All colour measurements were made on a ICS Texicon Spectroflash 500. Colour difference was measured using the CMC equation and D65 illuminant and whiteness was calculated using the CIE equation.

\subsubsection{Colour fastness}

The procedure used for colour fastness to rubbing was according to BS EN ISO 13934-1:1999. The procedure for colour fastness to water was according to BS ENO ISO 105-E01:1996. 
Table 1

Description of subjective handle ratings

\begin{tabular}{ll}
\hline Rating & Description \\
\hline 1 & Unacceptable \\
2 & Worse than Control \\
3 & No change-as Control \\
4 & Better than Control \\
5 & Much better than Control \\
\hline
\end{tabular}

\subsubsection{Subjective handle assessment}

The handle of the enzyme treated fabrics was compared with that of the Control sample, treated with no enzyme and rated on a scale from 1 to 5 , with a rating of 3 being "no change" as described in Table 1 .

\section{Results and discussion}

\subsection{Modification of Esperase and their activities}

Esperase was chemically modified by covalently linking onto Eudragit S100, a reversible soluble-insoluble polymer using carbodiimide coupling at $5 \mathrm{~L}$ and $50 \mathrm{~L}$ scales. Previous work has demonstrated the increase in molecular size of proteases by covalently attaching proteases onto this soluble polymer [8]. Table 2 shows the protein concentration and activities of native and modified Esperases. Although the protein concentration of modified Esperase is much lower than the native enzyme due to dilution in the process of modification, the activity of modified enzyme still remained high based on the same level of protein concentration.

In order to maximise the usage of enzymes for wool processing, the stability of native Esperase and modified Esperase towards the soluble protein casein at the range of optimum temperature were determined and compared. Table 3 shows a much higher retention of activity of modified Esperase after $1 \mathrm{~h}$ treatment at $55^{\circ} \mathrm{C}$. The thermal stability of the modified Esperase is better than that of the native Esperase. This agrees with the

Table 2

Activities of native Esperase and modified Esperase towards dimethyl casein at $37^{\circ} \mathrm{C}$

\begin{tabular}{llcl}
\hline Protease & $\begin{array}{l}\text { Protein } \\
\text { concentration } \\
(\mathrm{mg} / \mathrm{mL})\end{array}$ & $\begin{array}{l}\text { Activity } \\
(\mathrm{U} / \mathrm{mL})\end{array}$ & $\begin{array}{l}\text { Activity/protein } \\
\text { concentration } \\
(\mathrm{U} / \mathrm{mg})\end{array}$ \\
\hline Native Esperase & 128.92 & 715 & 5.55 \\
Modified Esperase & 0.47 & 3.61 & 7.68 \\
\hline
\end{tabular}

Table 3

Stability of native Esperase and modified Esperase towards casein at $65^{\circ} \mathrm{C}$ and $55^{\circ} \mathrm{C}$

\begin{tabular}{lllll}
\hline Condition & & & \multicolumn{2}{l}{ Activity retained $(\%)$} \\
\cline { 1 - 2 } \cline { 5 - 5 } Temperature $\left({ }^{\circ} \mathrm{C}\right)$ & Time $(\mathrm{h})$ & & Native Esperase & Modified Esperase \\
\hline 65 & 0 & & 100 & 100 \\
& 1 & & 39.7 & 67.8 \\
55 & 0 & & 100 & 100 \\
& 1 & & 90.2 & 94.4 \\
\hline
\end{tabular}

Table 4

Effects of different pre-treatments and enzyme modification on felting shrinkage (\%) of the treated wool fabric

\begin{tabular}{lccccc}
\hline Samples & \multicolumn{3}{l}{ Area felting shrinkage (\%) } \\
\cline { 2 - 3 } \cline { 5 - 6 } \cline { 5 - 6 } & \multicolumn{2}{l}{ Pre-treatment method A } & & \multicolumn{2}{l}{ Pre-treatment method B } \\
\cline { 2 - 3 } \cline { 5 - 6 } & $60 \mathrm{~min}^{\mathrm{a}}$ & $120 \mathrm{~min}^{\mathrm{a}}$ & & $60 \mathrm{~min}^{\mathrm{a}}$ & $120 \mathrm{~min}^{\mathrm{a}}$ \\
\hline Control & 17.6 & 19.7 & & 14.0 & 15.2 \\
Native Esperase & 1.9 & 2.7 & & 2.1 & 1.8 \\
Modified Esperase & 4.0 & 2.8 & & 1.5 & 1.5 \\
\hline
\end{tabular}

a Enzyme treatment time.

results of the previous work on the characterisation of the modified Esperase [12].

\subsection{Effects of different pre-treatments and enzyme modification on the felting shrinkage and tensile properties of wool fabrics at pilot trials}

Application of the modified Esperase on the pre-treated wool fabrics was carried out at pilot scale for evaluating their effect on the shrink-resist and tensile properties of wool fabrics. Tables 4 and 5 show that all the enzyme treatments produced good levels of felting shrinkage control on the pre-treated wool fabrics. There was no major effect of the pre-treatment or source of modified enzyme on the tensile strength of the treated fabrics. The peak strain results for the same samples, following the same trends as the tensile strength results, confirming the higher degree of modification of the wool fabrics treated with the native Esperase.

After enzyme treatments, small samples of the fabrics from these pilot trials were dyed in the laboratory and their tensile strength measured. The results of these measurements are expressed in terms of the reduction in tensile strength of the fabrics which occurred during the dyeing process. The strength losses for samples treated with modified enzyme were similar to those for the control fabrics treated without enzyme, whereas

Table 5

Effects of different pre-treatments and enzyme modification on tensile properties of treated wool fabrics

\begin{tabular}{|c|c|c|c|c|}
\hline & \multicolumn{2}{|c|}{ Pre-treatment method A } & \multicolumn{2}{|c|}{ Pre-treatment method B } \\
\hline & $60 \min ^{a}$ & $120 \min ^{\mathrm{a}}$ & $60 \min ^{\mathrm{a}}$ & $120 \min ^{\mathrm{a}}$ \\
\hline \multicolumn{5}{|l|}{ Tensile strength (kgf) } \\
\hline Control & 29 & 28 & 29 & 30 \\
\hline Native Esperase & 27 & 25 & 24 & 22 \\
\hline Modified Esperase & 30 & 28 & 30 & 30 \\
\hline \multicolumn{5}{|l|}{ Peak strain $(\%)$} \\
\hline Control & 40 & 38 & 39 & 40 \\
\hline Native Esperase & 33 & 22 & 24 & 19 \\
\hline Modified Esperase & 40 & 30 & 36 & 33 \\
\hline \multicolumn{5}{|c|}{ Reduction in tensile strength on dyeing (\%) } \\
\hline Control & 8 & 7 & 9 & 10 \\
\hline Native Esperase & 23 & 39 & 20 & 35 \\
\hline Modified Esperase & 8 & 10 & 7 & 9 \\
\hline
\end{tabular}

${ }^{a}$ Enzyme treatment time. 
Table 6

Effects of different pre-treatments and enzyme modification on the whiteness of treated fabrics and their handle assessment ratings

\begin{tabular}{|c|c|c|c|c|}
\hline & \multicolumn{2}{|c|}{$\begin{array}{l}\text { Pre-treatment } \\
\text { method A }\end{array}$} & \multicolumn{2}{|c|}{$\begin{array}{l}\text { Pre-treatment } \\
\text { method B }\end{array}$} \\
\hline & $60 \min ^{\mathrm{a}}$ & $120 \min ^{\mathrm{a}}$ & $60 \min ^{\mathrm{a}}$ & $120 \mathrm{~min}^{\mathrm{a}}$ \\
\hline \multicolumn{5}{|l|}{ CIE whiteness index ${ }^{*}$} \\
\hline Control & -10 & -15 & 35 & 38 \\
\hline Native Esperase & 8 & 14 & 39 & 46 \\
\hline Modified Esperase & 4 & 12 & 36 & 41 \\
\hline \multicolumn{5}{|c|}{ Handle assessment rating } \\
\hline Native Esperase & 4 & 4.5 & 4.5 & 4.5 \\
\hline Modified Esperase & 3.5 & 3.5 & 3.5 & 3.5 \\
\hline
\end{tabular}

Note: CIE whiteness index of untreated wool fabric is 9.

a Enzyme treatment time.

a major reduction in strength occurred for samples treated with the native enzyme.

\subsection{Effect of pilot scale enzyme treatment on whiteness and handle of wool fabrics}

Whiteness measurements on the treated fabrics in Table 6 show that yellowing of the wool fabric occurred during the alkaline pre-treatment because the whiteness index of untreated wool fabric is 9. By contrast, the pre-treatment incorporated hydrogen peroxide in the alkaline liquor produced a bleaching effect on the wool. Treatments using the native enzyme and modified enzymes demonstrated a bleaching effect in that they removed much of the yellowing caused by the pre-treatment.

The time of treatment with modified enzyme had less effect on fabric properties than for the native enzyme, which does suggest that the modified enzyme is effectively restricted to the fabric's surface. There was an indication in the felting shrinkage control properties of the treatments, that the 120 min treatment gave a slightly improved result over the 60 min treatment.

The potential advantage of the alkaline pre-treatment is that it could ultimately lead to a single bath process with enzyme application. The wool fabrics would first be subjected to the sodium carbonate pre-treatment, then the modified enzyme would be added and at the end of this treatment the bath could be made acidic and the fabric could be dyed from the same bath. This would offer benefits in savings in water usage, energy and process time. Additionally, this alkaline pre-treatment would adjust the $\mathrm{pH}$ of the fabric prior to the enzyme treatment, so that the enzyme treatment would be less sensitive to variations in the acidity of fabrics received for treatment.

\subsection{Bulk trial for the industrialisation process for enzyme treatments of wool}

Scaling-up for the industrialisation process was carried out in the $50 \mathrm{~L}$ jet dyeing machine, using a $10 \mathrm{~m}$ length of fabric made-up from $5 \mathrm{~m}$ of the $19 \mu \mathrm{m}$ fabric and $5 \mathrm{~m}$ of the $21 \mu \mathrm{m}$ fabric. Therefore, the liquor ratio for wool fabric reduced from $62.5: 1$ pilot scale to $12.5: 1$ bulk scale although the volume of liquor still remained at $35 \mathrm{~L}$. To be consistent, the quantity of chemicals and enzyme used at all the treatments are based on mass wool fabric. Table 7 shows the fabric properties of wool after pre-treatment and enzymatic process.

It can be found that the weight per square metre of the fabrics treated with modified enzyme was virtually the same as that of the untreated fabric which had been dry finished, which is a desirable result. It is still possible that some weight loss occurred during the modified-enzyme treatment, but that consolidation of the fabric during wet processing caused the base weight per unit area of the fabric to increase and compensate for any weight loss that occurred due to enzymatic degradation of the fibre. Because the fabric widths remained the same $(150 \mathrm{~cm})$ after finishing, this means that any consolidation might have occurred in the length dimension. The fabric treated with the native enzyme had a much lower weight per unit area, indicating significant weight loss due to enzymatic degradation of the wool.

The relaxation shrinkage measurements, based on the 7A wash test results, were all less than $3 \%$, which is a Woolmark requirement, and shows that the fabrics had been processed in a commercially acceptable manner. The modified enzyme treatments produced a machine washable finish on both the $19 \mu \mathrm{m}$ and $23 \mu \mathrm{m}$ wool fabrics, with area felting shrinkages of less than $3 \%$ in three wash cycles of $5 \mathrm{~A}$ washing test. Similarly,

Table 7

Test results for wool fabrics treated by the bulk enzymatic process

\begin{tabular}{|c|c|c|c|c|c|c|c|c|}
\hline \multirow[t]{2}{*}{ Batch samples } & \multirow{2}{*}{$\begin{array}{l}\text { Fabric weight } \\
\left(\mathrm{g} / \mathrm{m}^{2}\right)\end{array}$} & \multirow{2}{*}{$\begin{array}{l}\text { Area relaxation } \\
\text { shrinkage }(\%)\end{array}$} & \multicolumn{2}{|c|}{ Felting shrinkage $(\%)$} & \multirow{2}{*}{$\begin{array}{l}\text { Tensile strength } \\
\text { (kgf) }\end{array}$} & \multirow{2}{*}{$\begin{array}{l}\text { Peak strain } \\
(\%)\end{array}$} & \multirow{2}{*}{$\begin{array}{l}\text { Whiteness } \\
\text { index }\end{array}$} & \multirow{2}{*}{$\begin{array}{l}\text { Handle } \\
\text { assessment }\end{array}$} \\
\hline & & & Area & Cuff edge & & & & \\
\hline \multicolumn{9}{|l|}{$19 \mu \mathrm{m}$ wool } \\
\hline Untreated & 156 & 1.5 & 16.5 & 2.2 & 28.6 & 33.4 & -2.2 & 3 \\
\hline Native Esperase & 143 & 1.5 & -1.1 & 1.0 & 16.7 & 13.7 & 15.1 & 4 \\
\hline Modified Esperase & $\begin{array}{l}160 \\
( \pm 2.0)\end{array}$ & $\begin{array}{c}1.4 \\
( \pm 0.2)\end{array}$ & $\begin{array}{r}0.3 \\
( \pm 0.4)\end{array}$ & $\begin{array}{c}0.2 \\
( \pm 0.08)\end{array}$ & $\begin{array}{c}26.1 \\
( \pm 1.9)\end{array}$ & $\begin{array}{c}23.4 \\
( \pm 2.9)\end{array}$ & $\begin{array}{c}-0.8 \\
( \pm 1.9)\end{array}$ & $\begin{array}{c}3.2 \\
( \pm 0.27)\end{array}$ \\
\hline \multicolumn{9}{|l|}{$23 \mu \mathrm{m}$ wool } \\
\hline Untreated & 183 & 1.3 & 15.8 & 1.6 & 40.8 & 42.8 & -10.3 & 3 \\
\hline Native Esperase & 165 & 1.9 & 1.5 & 0.5 & 24.2 & 19.3 & 3.7 & 4 \\
\hline Modified Esperase & $\begin{array}{l}184 \\
( \pm 2.3)\end{array}$ & $\begin{array}{r}2.4 \\
( \pm 0.3)\end{array}$ & $\begin{array}{c}2.2 \\
( \pm 0.17)\end{array}$ & $\begin{array}{r}0.7 \\
( \pm 0.3)\end{array}$ & $\begin{array}{c}35.7 \\
( \pm 1.7)\end{array}$ & $\begin{array}{c}28.7 \\
( \pm 3.8)\end{array}$ & $\begin{array}{c}-4.6 \\
( \pm 1.5)\end{array}$ & $\begin{array}{c}3.3 \\
( \pm 0.27)\end{array}$ \\
\hline
\end{tabular}

Note: Value in the brackets is standard deviation of five batch repeats. 
Table 8

Test results for $19 \mu \mathrm{m}$ wool fabrics treated with enzyme and then dyed

\begin{tabular}{|c|c|c|c|c|c|c|c|c|c|c|}
\hline \multirow[t]{2}{*}{ Batch samples } & \multirow{2}{*}{$\begin{array}{l}\text { Fabric weight } \\
\left(\mathrm{g} / \mathrm{m}^{2}\right)\end{array}$} & \multirow{2}{*}{$\begin{array}{l}\text { Area relaxation } \\
\text { shrinkage }(\%)\end{array}$} & \multicolumn{2}{|c|}{ Felting shrinkage $(\%)$} & \multirow{2}{*}{$\begin{array}{l}\text { Tensile } \\
\text { strength (kgf) }\end{array}$} & \multirow{2}{*}{$\begin{array}{l}\text { Peak strain } \\
(\%)\end{array}$} & \multirow{2}{*}{$\begin{array}{l}\text { Handle } \\
\text { assessment }\end{array}$} & \multicolumn{2}{|c|}{ Rub fastness } & \multirow{2}{*}{$\begin{array}{l}\text { Colour fastness } \\
\text { to water }\end{array}$} \\
\hline & & & Area & Cuff edge & & & & Dry & Wet & \\
\hline Untreated & 162 & 2.5 & 15.7 & 2.1 & 28.9 & 26.6 & 3 & 4.5 & 4.0 & 4.5 \\
\hline Native Esperase & 149 & 2.9 & -2.1 & 0.2 & 12.8 & 10.3 & 4.5 & 3.0 & 1.5 & 4.5 \\
\hline Modified Esperase & 167 & 3.3 & 0.7 & 0.5 & 22.1 & 17.7 & 3 & 4.5 & 4.0 & 4.5 \\
\hline
\end{tabular}

the cuff-edge shrinkage results were all less than $1.0 \%$. These results meet the Woolmark requirement for a wool fabric to be described as "Machine Washable". Correspondingly, the tensile strength of the fabrics treated with the modified enzyme was slightly lower than for the untreated fabric, but they would be considered to be acceptable.

Fabrics treated with the native Esperase would also meet the Woolmark requirements for machine washability, but the fact that one of the samples expanded in the wash test, rather than shrank, suggests that the wool in this fabric had been badly degraded by the treatment with native enzyme. This can be confirmed by the low value of fabric tensile strength and peak strain.

The whiteness index results shows that in these bulk treatments the whiteness of the fabrics treated with the modified enzyme was slightly better than that of the untreated fabric. The fabrics treated with the native enzyme had been bleached to a greater extent, evidenced by the higher whiteness index.

The subjective assessment of the handle of the fabrics indicated that there was no major difference between the handle of the untreated fabric and that of fabrics treated with the modified enzyme. Conventional chlorination shrink-proofing treatments are known to harshen the handle of treated fabrics as well as to cause yellowing, so the fact that the modified enzyme produces neither of these negative effects is a significant advantage.

\subsection{Bulk trials for dyeing the enzyme treated wool fabrics}

The effect of enzymatic treatment with native and modified protease on the dyeing properties of wool was investigated at bulk trial. The treated fabric samples were dyed with acid dyes in to a navy shade. During the dyeing process, it is found that the quality of all the dyeings for fabrics treated with modified enzyme was judged to be very good; the dyeings were level and there was good penetration of the dye. The colour fastness results for the dyed fabrics are shown in Table 8 . The rub fastness for fabrics treated with the modified enzymes was the same as for the untreated fabric. In the case of water fastness, the degree of staining onto the multi-fibre strip was essentially the same as for the untreated fabric. These are particularly encouraging results, because it is well known that degradative shrink-proofing treatments such as chlorination, can affect significantly the dyeing properties of wool fabrics. Whilst some minor changes may need to be made to the dyeing procedures, there do not seem to be any major problems associated with dyeing wool which has been treated with modified enzyme.

The enzymatic process for fabrics treated with modified enzyme produced a slight loss in strength, but the reduction was minor compared with that for fabrics treated with the native Esperase. The relative handle of the treated fabrics was unaffected by the dyeing process and the results were comparable to those for the undyed fabrics.

\section{Conclusions}

It has been shown that chemically modification of proteases with Eudragit improved the thermal stability of enzymes. The large scale trials have demonstrated that the modification of the enzyme does control the reaction of the enzyme with the wool, and in all cases less degradation of the wool occurred than in similar treatments with the native Esperase. The modified Esperase produces an anti-felting effect on the trial fabrics and the shrinkage values for treated fabrics in the 7A and 5A tests were within the Woolmark requirements for a machine washable fabric.

The dyeing properties of wool fabrics appear to be unaffected by treatment with modified Esperase and dyed fabrics show good colour fastness properties. From the single bulk trial carried out, it appears feasible to omit the sodium carbonate pre-treatment and to dye the fabric from the same bath used to apply the modified Esperase. This route offers significant savings in water and energy usage and process time.

\section{Acknowledgements}

We thank the European Commission for funding this project work (G1RD-CT-2002-00695) and Novozymes for enzyme samples and advice on enzyme applications.

\section{References}

[1] Fornelli S. Enzymatic treatment of protein fibres - state-of-the-art biotechnology. Dyer 1993;178:29-33.

[2] Nolte H, Bishop DP, Hocker H. Effects of proteolytic and lipolytic enzymes on untreated and shrink-resist-treated wool. J Text Inst 1996;87:212-26.

[3] Breier R. Lanazym process: purely enzymatic antifelt finishing of wool. Melliand English 2000;4:E77-9.

[4] Heine E, Hocker H. Enzyme treatments for wool and cotton. Rev Prog Coloration 1995;25:57-63.

[5] Bishop D, Shen J, Heine E, Hollfelder B. The use of proteolytic enzymes to reduce wool fibre stiffness and prickle. J Text Inst 1998;89(Part 1, No. 3):546-53.

[6] Shen J, Bishop D, Heine E, Hollfelder B. Some factors affecting the control of proteolytic enzyme reactions on wool. J Text Inst 1999;90(Part 1, No. 3):404-11.

[7] Heine E, Hollfelder B, Shen J, Bishop D. Parameters affecting the morphology of wool during enzyme treatment. In: The 10th international wool textile research conference. 2000. 
[8] Shen J. A new approach for the enzymatic treatment of wool for shrink resistance. In: 3rd international conference on textile biotechnology. 2004.

[9] Silva CJSM, Sousa F, Gübitz G, Cavaco-Paulo A. Chemical modifications on proteins using glutaraldehyde. Food Technol Biotechnol 2004;42(1):51-6

[10] Silva CJSM, Gübitz G, Cavaco-Paulo A. Optimization of a serine protease coupling to Eudragit S-100 by experimental design techniques. J Chem Technol Biotechnol 2005;81:8-16.
[11] Lenting HBM, Schroeder M, Gübitz GM, Cavaco-Paulo A, Shen J. A new enzyme technology based method for obtaining machine washable wool. In: 11th international wool conference. 2005.

[12] Silva CJSM, Zhang Q, Shen J, Gubitz G, Cavaco-Paulo A. Immobilization of proteases with a water soluble-insoluble reversible polymer for treatment of wool and enzyme recycling. Enzyme Microb Technol 2006;39:634-40.

[13] Lowry OH, Rosenberg WJ, Farr AL, Randell RJ. Quantitation of protein using Folin Ciocalteau reagent. J Biol Chem 1951;193:265-75. 